\title{
The Effect of Cognitive, Affective and Psychomotor Development on Children's Creativity in Education Games of Al-Khairaat Kindergrten at Palu City
}

\author{
Fatimah Saguni \\ Tarbiyah and Education Science Faculty of IAIN Palu, Central Sulawesi, Indonesia
}

\begin{abstract}
This study aims are : (1) to determine the effect of cognitive development on children's creativity in educational games of Al-Khairaat kindergarten at Palu City, (2) to find the effect of affective development on children's creativity in educational games of Al-Khairaat kindergarten at Palu City, (3) to know the effect of psychomotor development on children's creativity in educational games of Al-Khairaat kindergarten at Palu City.The method used is quantitative. There are three independent variables of (X1) Cognitive Development, (X2) Affective Development and (X3) Psychomotor Development and one dependent variable of (Y) Kindergarten Children Creativity. This research was conducted at Al-Khairaat Kindergarten in Palu City, Central Sulawesi. The data was collected by five point Likert scale and analyzed by regression analysis with SPSS version 21 software. The results are follows. First, cognitive development had a very significant effect on children's creativity. This means that education by drawing, colouring, arranging blocks, children paying attention to understand game that can enhance his creativity. Second, affective development has a very significant effect on children's creativity. This means that educational education by drawing, colouring, arranging blocks, playing with peers, happy with presence of interesting game tools increase creativity. Third, psychomotor development has a very significant effect on children's creativity. This means that educational education by moving, running and jumping can train children to increase their creativity.
\end{abstract}

Keywords: Cognitive Development, Affective, Psychomotor, Kindergarten Child Creativity.

DOI: $10.7176 / \mathrm{JEP} / 10-4-06$

\section{INTRODUCTION}

The education has goal to develop and optimize the children ability physically, and intellectually. De Orther (in Yulani Nurani Sujiono, et al., 2011) showed theory of Quantum Learning revealed that humans as individuals have potential to growth at almost unlimited. What is used is only part of the capabilities. This is due to unsuitable media to develop these abilities. Therefore, teacher has role to maximize the attention to media usage since in Kindergarten. Kindergarten education is one form of early children education with an important role to develop children's personalities and preparing them for further education. Kindergarten education is a bridge between the family environment and wider community, namely elementary school and other environments

Kindergarten is a form of early children education within formal education line, as stated in National Education System Law Number 20 year 2003 Article 28 on Early children education at formal education in form of Kindergarten, Raudhatul Athfal, or other equivalent form. Early Children Education (ECD), especially Kindergarten, needs to provide various activities to develop developmental aspects of cognitive, language, social, emotional, physical and motor.

Early children education is a fundamental education in life a child and greatly determines the continuity of child itself also for a nation. Therefore, early children are asset and future investment for a nation. Indonesia in future twenty-five-year will depend on early children today. Early children education needs very serious attention from various parties, both the government, community and other related parties for the human resources development.

Sujiono (2009) stated that early children are a group of individuals in range of 0-8 years old, a group of people who are in process of growth and development. Early age is a golden age for individual development. The children experience extraordinary growth and development in physical, language, cognitive, artistic, moral, religious values, social emotional and independence aspects.

Santoso (2002) stated that early children are an individual figure as a sociocultural being in developmental process that fundamental to future life and has a number of certain characteristics. Early children are innocent humans with the potential to be developed. Children have certain unique characteristics that different with adults and will develop into full human beings. Children have various kinds of potential that must be developed, although generally children have the same pattern of development but the rhythm will be different each other because basically children are individual. The success of one's life is determined by how the education, treatment, and care in early years of his life. Early children have age range of 0-6 years who experiencing very rapid growth and development. Therefore, appropriate stimulation is needed in order to grow and develop optimally. Even education that starts in preschool toddlers (4-6 years) is actually too late. 
Various studies in neurology found that $50 \%$ of children's intelligence capacity is formed in first four years since birth. The child at eight years old has brain development of $80 \%$ and completely $100 \%$ at 18 old. Ages $0-8$ years are a golden period for child development because $80 \%$ of brain development that age range. The human brain is a hologram that can record, absorb, store, reproduce and reconstruct information. The brain ability is effected by activities of these neurons based on quality and frequency of stimulation received by senses. Stimulation in first years of a children's life greatly affects the physical structure of a children's brain, and this is difficult to repair in later life. The implication is the children with rare psychosocial stimulation as being rarely touched or rarely invited to play will experience various behavioural aberrations (Hendarti Permono, 2013).

The special characteristics in early children need a specific education. Early Children Education or Early Children Care and Education (ECCE) has the potential to develop social, language and communication and motor skills in early children. This can be done if the educational environment can support their imagination and pleasant educational environment for them (Bowman, et al., In Dwi Prapsiwi). Therefore, ECCE has purpose to fulfil children's rights to obtain education as early as possible and also to provide a foundation for children's growth and development in all aspects, both skills, social, academic and morality (Rochaety, in Prapsiwi, 2012). Therefore, ACCE learning must be adjusted to stages of development of students. Children can be given the opportunity to develop their creativity freely, both through the scratch they make, stories, and other works. Efforts to improve the quality of cognitive development are backed by education and training to research and finding exercises, which require the function of both hemispheres. The imposition of brain with memorizing knowledge, repetition exercises and drill, will not fully realize the advancement of cognitive development. It will even make a person not think creatively, and make cognitive development lead primarily to convergent thinking results (Semiawan in Yuliani Nurani Sujiono et al. (2011)

There are three domains related to human development, namely cognitive, affective and motor. Although these developmental domains are usually studied as individual units, we must remember that these domains are constantly interact each other. Everything we do in motor domain is affected by our emotions, social interaction, and cognitive development. Therefore, all behavior in affective and cognitive domain are strongly affected by motor behavior.

\section{Cognitive Development}

Cognitive development describes how a children's mind develops and functions in order he can think (Mansur). Cognitive development is a mental process to understand the world, discover knowledge, make comparisons, and thinking. The mental process in question is an information processing to reaches cognition, intelligence, learning, problem solving and concept formation activities (Endang Purwanti and Nur Widodo).

Bloom (1956) said that all brain activities were divided into 6 levels according to lowest to highest levels. They were symbolized by $\mathrm{C}$ (Cognitive), with following description

a) $\mathrm{C} 1$ (Knowledge). This level emphasizes on the ability to recall the studied material, such as knowledge of terms, special facts, conventions, trends and sequences, classifications and categories, criteria and methodologies.

b) $\mathrm{C} 2$ (Comprehension). This level defines comprehension as the ability to understand certain material learned.

c) C3 (Application). This level interprets application as the ability to apply information to real situations, where students can apply their understanding by in a real way.

d) C4 (Analysis). This level defines analysis as the ability to decipher a material into clearer components.

e) C5 ( Synthesis). This level asked students to elaborate information into several parts to find assumptions, and distinguish opinions and facts to find causal relationships.

f) C5 (Synthesis). This level defines synthesis as the ability to produce and combine elements to form a unique structure.

g) C6 (Evaluation). This level defines evaluation as the ability to assess the benefits of a thing for a particular purpose based on clear criteria.

\section{Affective development}

Affective development deals with attitudes and values. Some experts said that a person's attitude can be predicted for change if someone already has a high level of cognitive mastery. Affective learning assessment received less attention from teacher. This measure is only based on cognitive aspects. Bloom (1956) divided the affective domain into 5 categories, namely:

a) Receiving / Attending. This category is the lowest affective level to includes acceptance of problems, situations, symptoms, values and beliefs passively.

b) Responding. This category concern to answers and pleasure of responding or realizing something in accordance with values adopted by community.

c) Valuing. This category concerns with providing value, appreciation and trust in a particular symptom or 
stimulus. Students can accept the values taught and also have the ability to judge the phenomenon weather good or bad.

d) Organization. This category includes the conceptualization of values into a value system, as well as strengthening and prioritizing the values owned. This can be exemplified by ability to weigh the positive and negative consequences of a scientific advance on human life.

e) Characterization. This category deals with integration of all the value systems a person to affect his personality and behavior patterns. The process of internal values is the highest in value hierarchy.

\section{Psychomotor Development}

Psychomotor development is a domain related to skills or the ability to act after someone receives a certain learning experience. Psychomotor is an ability to prioritizes on physical skills consisting of perception, readiness, guided movement, accustomed movements, complex movements, adjustment of movement patterns, and creativity. Octavia (2015) stated that psychomotor domain related to skills or the ability to act after a child receives certain learning experiences.

This domain includes the competence to work by involving members of body as well as competencies related to motion (motor) which consists of reflex movements, basic movement skills, perceptual abilities, accuracy, complex skills, expressiveness and interpretation. The categories included in this domain are below.

a) Mimicking. This category is the ability to do something based on observed example even though the meaning or essence of skill is not yet understood.

b) Manipulation. This category is the ability to carry out an action and choose what is needed from the taught.

c) Experience. This category is an appearance of action where things taught and made as examples have become a habit and movements shown in more convincing.

d) Articulation. This category is a stage where one can perform a more complex skill, especially to deals with interpretive movements.

\section{Creativity}

Gallagher (2010) said that creativity is a mental process of individuals in form of new ideas or products, or combining both of them which finally attached to him. In addition, Clarkl (1994) said that creativity is an experience and actualizing individual identity integrally between self-relationship, nature and others.

The creativity development through play activities is directed to stimulate children ability, to create new combinations, ability to produce unusual responses, and stimulate children to think. One game to improve children's creativity is educational games.

Playing is a fun and spontaneous activity to gives psychological security to children. Atmosphere of active play gives children wide opportunities to explore to fulfil curiosity. Children are the happiest world, both from children themselves and parents. Parents see the child happy to laugh cheerfully and have fun is their own satisfaction. Children find their world properly and correctly to grow and develop well, as shown in figure 1 .

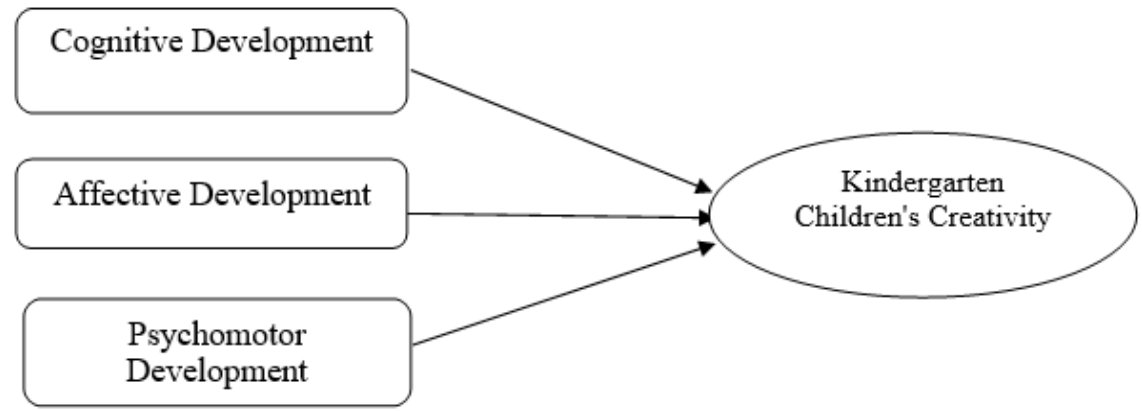

Figure 1. Flow of Cognitive, Affective and Psychomotor Developmental Analysis on Kindergarten Children's Creativity.

\section{METHOD}

This research is a quantitative research. The data analysis technique used is multiple regression analysis to determine the effect of independent variables on dependent variable. Arikunto (2010) said that quantitative research demanded to use numbers, starting from data collection, interpretation, and results presentation. Purwanto (2012) considers that quantitative research is affected by natural phenomena that are objective, orderly and predictable and the quality results are scaled into quantitative numbers in collection and analysis of data.

The data was analyzed by multiple regression analysis to determine the relationship between independents variables on dependent variable. There are four variables, namely three independent variables of Cognitive development(X1), Affective development(X2),) Psychomotor development (X3 and one dependent variable of Creativity (Y). The data is collected by questionnaires and measured by five point Likert scale, from $5=$ very agree, 
4=agree, $3=$ netral, $4=$ disagree and 5=strongly disagree. Questionnaires were distributed to kindergarten teachers. The collected data is analyzed by SPSS version 21 .

\section{RESULTS AND DISCUSSION}

\section{A. Research Results}

This research was conducted on 16 research subjects. The results of study were divided into 3 sub-sections, namely the description and data categories, prerequisite tests, and hypothesis testing. The results of study can be described below.

\section{Description and Category of Research Data}

The results of statistical description tests for four (4) research variables can be seen in Table 1.

Table 1. Data Description $(\mathrm{N}=16)$

\begin{tabular}{|c|c|c|c|c|c|c|c|c|}
\hline \multirow{3}{*}{ Variables } & \multicolumn{4}{|c|}{ Hypothetical Data } & \multicolumn{4}{|c|}{ Empirical Data } \\
\hline & \multicolumn{2}{|c|}{ Score } & \multirow{2}{*}{ Mean } & \multirow{2}{*}{ SD } & \multicolumn{2}{|c|}{ Score } & \multirow{2}{*}{ Mean } & \multirow{2}{*}{ SD } \\
\hline & Min & Max & & & Min & Max & & \\
\hline Child creativity & 25 & 70 & 47.5 & 7.5 & 38 & 62 & 50.13 & 8.164 \\
\hline Cognitive development & 25 & 70 & 47.5 & 7.5 & 38 & 63 & 51.13 & 7.219 \\
\hline Affective development & 25 & 70 & 47.5 & 7.5 & 41 & 61 & 51.06 & 6.038 \\
\hline Psychomotor development & 25 & 70 & 47.5 & 7.5 & 38 & 61 & 49.13 & 7.136 \\
\hline
\end{tabular}

Table 1 is used to calculate data categories for each research variable. The categories of each research variable are as below.

\section{a. Children's Creativity}

Category of children creativities are shown in table 2.

Table 2. Categories of children creativity

\begin{tabular}{cccccc}
\hline \multirow{2}{*}{ No. } & Score & & Category & $\begin{array}{c}\text { Frequency } \\
(\mathrm{f})\end{array}$ & $\begin{array}{c}\text { Percent } \\
(\%)\end{array}$ \\
\hline 1. & $\mathrm{X} \geq(\mu+1 \sigma)$ & $\mathrm{X} \geq 55$ & High & 5 & 31.3 \\
2. & $(\mu-1 \sigma) \leq \mathrm{X}<(\mu+1 \sigma)$ & $40 \leq \mathrm{X}<55$ & Medium & 11 & 68.8 \\
3. & $\mathrm{X} \leq(\mu-1 \sigma)$ & $\mathrm{X} \leq 40$ & Low & - & - \\
\hline & & & Total & 16 & 100.0 \\
\hline
\end{tabular}

Description: $\mathrm{X}=$ subject score, $\mu=$ hypothetical mean, $\sigma=$ hypothetical standard deviation (SD).

Table 2 showed 11 children $(68.8 \%)$ have moderate category for children's creativity, 5 children $(31.3 \%)$ in high category and zero for low category. It can be concluded that most subjects have medium creativity.

b. Cognitive development

Categories of cognitive development is shown in table 3 .

Table 3. Categories of cognitive development

\begin{tabular}{|c|c|c|c|c|c|}
\hline No. & \multicolumn{2}{|c|}{ Score } & Category & $\begin{array}{l}\text { Frequency } \\
\text { (f) }\end{array}$ & $\begin{array}{c}\text { Percent } \\
(\%)\end{array}$ \\
\hline 1. & $\mathrm{X} \geq(\mu+1 \sigma)$ & $X \geq 55$ & High & 4 & 25.0 \\
\hline 2. & $(\mu-1 \sigma) \leq X<(\mu+1 \sigma)$ & $40 \leq \bar{X}<55$ & Medium & 11 & 68.8 \\
\hline 3. & $X \leq(\mu-1 \sigma)$ & $X \leq 40$ & Low & 1 & 6.2 \\
\hline & & & Total & 16 & 100.0 \\
\hline
\end{tabular}

Description: $\mathrm{X}=$ subject score, $\mu=$ hypothetical mean, $\sigma=$ hypothetical standard deviation (SD).

Table 3 shows that 11 children $(68.8 \%)$ have moderate development cognitive categories, 4 children $(31.3 \%)$ in high category, while 1 person $(6.2 \%)$ in low category. It can be concluded that majority of subjects have medium cognitive development.

c. Affective development

Categories of affective development is shown in table 4.

Table 4. Categories of affective development

\begin{tabular}{|c|c|c|c|c|c|}
\hline No. & & & Category & $\begin{array}{l}\text { Frequency } \\
\text { (f) }\end{array}$ & $\begin{array}{l}\text { Percent } \\
(\%)\end{array}$ \\
\hline 1. & $X \geq(\mu+1 \sigma)$ & $X \geq 55$ & Tinggi & 4 & 25.0 \\
\hline 2. & $(\mu-1 \sigma) \leq X<(\mu+1 \sigma)$ & $40 \leq X<55$ & Sedang & 12 & 75.0 \\
\hline 3. & $X \leq(\mu-1 \sigma)$ & $X \leq 40$ & Rendah & - & - \\
\hline
\end{tabular}

Description: $\mathrm{X}=$ subject score, $\mu=$ hypothetical mean, $\sigma=$ hypothetical standard deviation (SD).

Table 4 shows 12 children $(75.0 \%)$ have moderate category affective development, 4 children $(25.0 \%)$ in high category, whereas in low category are not found. It can be concluded that most subjects have medium affective development subjects. 
Table 5. Categories of psychomotor development

\begin{tabular}{|c|c|c|c|c|c|}
\hline No. & \multicolumn{2}{|c|}{ Score } & \multirow{2}{*}{$\frac{\text { Category }}{\text { Low }}$} & \multirow{2}{*}{$\begin{array}{c}\text { Frequency } \\
\text { (f) }\end{array}$} & \multirow{2}{*}{$\begin{array}{c}\begin{array}{c}\text { Percent } \\
(\%)\end{array} \\
25.0\end{array}$} \\
\hline 1. & $\mathrm{X} \geq(\mu+1 \sigma)$ & $X \geq 55$ & & & \\
\hline 2. & $(\mu-1 \sigma) \leq X<(\mu+1 \sigma)$ & $40 \leq X<55$ & Medium & 12 & 75.0 \\
\hline \multirow[t]{2}{*}{3.} & $X \leq(\mu-1 \sigma)$ & $X \leq 40$ & High & - & - \\
\hline & & & Total & 16 & 100.0 \\
\hline
\end{tabular}

Description: $\mathrm{X}=$ subject score, $\mu=$ hypothetical mean, $\sigma=$ hypothetical standard deviation (SD).

Table 5 shows that 12 children $(75.0 \%)$ have moderate category psychomotor development, 4 children $(25.0 \%)$ in high category, whereas in low category are not found. Based on these results it can be concluded that majority of subjects have psychomotor development subjects tend to be moderate.

\section{a. Regression test results}

The multiple regression test is regression model enter. Regression tests were conducted to see the simultaneous relationship of cognitive development, affective development and psychomotor development on kindergarten children's creativity. The results is shown in table 6 .

Table 6. Regression analysis

\begin{tabular}{lcc}
\hline \multicolumn{1}{c}{ Predictor } & Children Creativity & Sig. \\
\hline Cognitive development & $\mathrm{A} 0.224$ & 0.440 \\
Affective development & 0.130 & 0.657 \\
Psychomotor development & 0.789 & $0.001^{* *}$ \\
$\mathrm{R}_{\mathrm{xy}}$ & 0.975 & $0.001^{* *}$ \\
$\mathrm{R}^{2}$ & 0.950 & $0.001^{* *}$ \\
$\mathrm{~F}$ & 75.489 & $0.001^{* *}$ \\
\hline
\end{tabular}

Description:

$* \mathrm{p}<0.05 ; * * \mathrm{p}<0.01$ (significant).

$\mathrm{Rxy}=$ regression coefficient, $\mathrm{R} 2=$ coefficient of determination, $\mathrm{F}=$ regression variant

b. Regression test results

Regression results is used to analyze the partial hypotheses for the effect of (1) cognitive development on children's creativity; (2) affective development and children's creativity, and (3) psychomotor development on children's creativity. Dahlan (2008) categorized the correlation very (0.00-0.199), weak (0.20-0.399), moderate (0.40-0.599), strong (0.60-0.799) ) and very strong (0.80-1.00). The results of statistical tests can be seen in table 7.

\section{Table 7. Correlation Test}

\begin{tabular}{lcc}
\hline \multirow{2}{*}{ Independent Variables } & \multicolumn{2}{c}{ Children Creativity (Dependent Variable) } \\
\cline { 2 - 3 } & Correlation Coefficient $(r)$ & $0.001^{* *}$ \\
\hline Cognitive development & 0.930 & $0.001^{* *}$ \\
Affective development & 0.867 & $0.001^{* *}$ \\
\hline
\end{tabular}

Description: $* \mathrm{p}<0.05 ; * * \mathrm{p}<0.01$

Table 7 shows that partially the effect of cognitive development, affective development and psychomotor development on kindergarten children's creativity are significant $(\mathrm{p}<0.05)$. Cognitive development variables have a very strong relationship with kindergarten children's creativity at $r=0.930$ (0.80-1.00). Affective development variables have a very significant relationship with kindergarten children's creativity at $r=0.867(0.80-1.00)$, and psychomotor development has a very significant relationship with kindergarten children's creativity at $r=0.970$ (0.80-1.00).

\section{B. DISCUSSION}

1. The effects of Cognitive Development on Children's Creativity in Educational Games of Al-Khairaat Kindergarten at Palu City

The results showed that cognitive development has significant effect on and kindergarten children's creativity $r=$ 0.930 (0.80-1.00). This means that higher the cognitive development increase creativity, and conversely the lower the cognitive development decrease creativity of Al-Khairaat Kindergarten at Palu City. Playing children essentially learn about many things. Every game presented in kindergarten has its own educational side. Unconsciously, children have learned many things by playing.

Mansur (2015) said that cognitive development describes how the children's mind develops and functions so that they can think. Additionally, Endang and Widodo (2015) said that cognitive development is a mental process to include comprehension of world, discovery of knowledge, making comparisons, thinking and understanding. 
The mental process is an information processing to reaches to activities of cognition, intelligence, learning, problem solving and concept formation. It also reaches creativity, imagination and memory.

2. The effects of Affective Development on Children's Creativity in Educational Games of Al-Khairaat Kindergarten at Palu City

Affective development relates with attitudes and values. Some experts say that a person's attitude can be predicted. This aspect of attitude can set an example not at theoretical level. Sujiono (in Khadijah) revealed that early children are a newborn child until 6 years old. Early age is a very decisive age to create character and personality of child. Children at 4- 6 years old develop nerve connections to function properly to coordinate the brain and motion, both physically and non-physically. Playing develops the social emotional aspects of children to create sense of belonging, feeling part of group, learning to live and working together in groups with all the differences that exist. Playing in groups make the children also learn to adjust their behavior with other children, learn to master themselves and their ego, learn to hold back, be able to regulate emotions, and learn to share with others. In terms of emotions, unspoken desires are also increasingly formed when children play imagination and sociodrama (Rohani, 2016).

The world of children cannot be separated from world of play and almost all children's activities play with a game tool. This game tool cannot be separated from children needs. Kindergarten teachers should have a good understanding of game tools used for learning in kindergarten. This game tool become kindergarten learning and addition to meeting children's instincts of playing and also a source of learning that is indispensable to develop kindergarten children. The success of one's life is determined by how he obtained education, treatment, and care in early years of his life. Early children have range of 0-6 years old with very rapid growth and development, so that appropriate stimulation is needed in order to grow and develop optimally.

\section{Effect of Psychomotor development on Children's Creativity in Educational Games of Al-Khairaat Kindergarten at Palu City}

The results showed that psychomotor development has a positive and significant effect on kindergarten children's creativity. This means that higher the psychomotor development increase the creativity, and conversely lower psychomotor development will decrease kindergarten children's creativity. It shows the study results is consistent with opinions expressed by Diana Mutia in Spirituality that through playing, can control motor skills. During that play, they can practice all motor movements such as running, jumping and other movements with aim to improve their movements even though they are not systematically organized but are meaningful or desired for motor movements. Children are encouraged to lift, carry, walk or jump, spin, and switch responses to rhythm they hear. The steps above must be proven in process of teaching and learning activities and teacher must be participatory, active, creative, innovative and fun, teacher does the learning by doing these activities. Psychomotor skills are all activities that are concrete and easily observed, both in quantity and quality, because of their open nature.

Based on the description it can be concluded that psychomotor development is a process of growth and development of a children's ability. Every movement carried out by children are the result of a complex pattern interactions of various parts and systems in body controlled by brain.

This study results are supported by Elizabeth $\underline{B}$ Hurlock that motor development is defined as the development of element of maturity controlling the movement of body and brain as the center of motion. This motion is clearly distinguished into rough and smooth motion. In addition, Sukamti Endang Rini said that motor development is a process of maturity or motion that directly involves the muscles to move and nerve process that becomes a person that can to move and process the nerve which makes a person capable to move his body.

These psychomotor learning outcomes are a continuation of cognitive learning outcomes and affective learning outcomes that are only visible in form of behavioural tendencies. This domain includes the competence to do job by involving members of body as well as competencies related to motor movement consisting of reflex movements, basic movement skills, perceptual abilities, accuracy, complex skills, and expressiveness and interagency.

\section{CONCLUSION}

The first hypothesis suggests that cognitive development affect on children's creativity in educational games of Al-Khairaat Kindergarten at Palu City. Educational education by drawing, colouring, arranging blocks, understanding what is being done can improve their creativity, because children's development already has the ability to store information that comes from vision, hearing, and information absorbed through other senses. In addition, children also have the ability to respond to these information systematically. This stage helps to explain how children think, store information and adapt to their environment. a recent study that uses sophisticated brain scanning techniques show the children's brains appear to experience substantial anatomical changes between the ages of three and fifteen.

The second hypothesis states that affective development affects on children's creativity in educational games of Al-Khairaat Kindergarten at Palu City. Educational education by drawing, colouring, arranging blocks, understanding what is being done can improve their creativity. Children receive information through the media as 
a game material to stimulate nerve circuits through games, Development of emotional aspects in children can express various emotions in playing. Children play because he feels happy to do it. The children's ability to create ideas, through games that provide an opportunity to experiment with feelings, desires and hopes, can release the tension that is in him. Children can channel feelings and channel the drives to make children relieved and relaxed.

Third Hypothesis states that psychomotor development affects on children's creativity in educational games of Al-Khairaat Kindergarten at Palu City. Motor development is a process of growth and development of a children's ability. Every movement carried out by child is the result of a complex pattern of interactions from various parts of body that are controlled by brain. The children's ability to sit, run, jump, catch the ball, and kick involve body movements to make the children's body health and muscles become strong.

\section{REFERENCES}

Ahmad, Suriansyah Aslamiah. 2011. Strategi Pembelajaran Anak Usia Dini. Banjarmasin. Comdes.

Arikunto, Suharsimi. 2010. Prosedur Penelitian Suatu Pendekatan Praktek. Jakarta: Rineka Cipta.

Asmawati Luluk. 2013. Pengelolaan kegiatan Pengembangan Anak Usia Dini. Banten: Cet. 12; Ed.I. Penerbit Universitas Terbuka.

Bloom, Benjamin. 1956. Taxonomy of Educational Objectives. Handbook 1: Cognitive Domain. New York: McKey.

Clark, Moustakas. 1994. Phenomenological Research Methods, California: SAGE

Departemen Agama RI. 2011. Transilleterasi Arab-Latin (Rumy). Al-Qur'an dan terjemahnya (Revisi Terbaru). Semarang: Penerbit C.V. Asy-syifa.

Endang, Purwanti dan Nur Widodo. 2015. Perkembangan Peserta Didik. Malang: Universitas Muhamadiyah Malang.

Gallagher, James J. 2010. Kemampuan Kreatifitas Anak Usia Dini, Surabaya: Grasindo.

Hendarti, Permono. 2013. Peran Orangtua dalam Optimalisasi Tumbuh Kembang Anak untuk Membangun Karakter Anak Usia Dini. Prosiding Seminar Nasional Parenting.

Htt://paud-anakbermain belajar.blogspot.com/2012/11/pengertia-dan-konsep-dasar-paud.html, accessed at 25 September 2017.

Hurlock. Elizabeth B. 1978. Perkembangan Anak Jakarta: Penerbit Erlan.

Mansur. 2015. Pendidikan Anak Usia Dini Dalam Islam, Yogyakarta: Pustaka Pelajar.

Mutia Diana. 2016. Rohani Mengoptimalkan Perkembangan Kognitif Anak Melalui Kegiatan Bermain. Raudhah: Vol. IV, No. 2.

Octavia, Rosa Friska. 2015. Analisis Kemampuan Siswa Kelas X pada Ranah Kognitif, Afektif dan Psikomotorik. Pendidikan Fisika, FKIP, Universitas Muhammadiyah Metro, Lampung. OMEGA Jurnal Fisika dan Pendidikan Fisika Vol 1, No 2.

Prapsiwi, Dwi. 2012. Pengelolaan Pembelajaran Anak Usia Dini. Artikel Publikasi Ilmiah. (Program Studi Manajemen Pendidikan Program Pascasarjana Universitas Muhammadiyah Surakarta.

Purwanti, E dan Nur Widodo. 2005. Perkembangan Peserta Didik. (Malang: Universitas Muhamadiyah Malang.

Purwanto. 2012. Metodologi Penelitian Kuantitatif untuk Psikologi dan Pendidikan. Yogyakarta : Pustaka Pelajar Offset.

Rohani. 2016. Mengoptimalkan Perkembangan Kognitif Anak Melalui Kegiatan Bermain. Raudhah: Vol. IV, No. 2, Issn: $2338-2163$ ) h. 17.

Santoso, Soegeng. 2002. Pendidikan Anak Usia Dini. Jakarta : Citra Pendidikan.

Yuliani, Nurani Sujiono. 2011. Metode Pengembangan Kognitif. Jakarta: Universitas Terbuka, 2011. 